\title{
DEVELOPING CRAFT AS A CREATIVE INDUSTRY THROUGH TOURISM
}

\author{
DESENVOLVENDO O ARTESANATO COMO UMA
}

INDÚSTRIA CRIATIVA ATRAVÉS DO TURISMO

\section{Greg Richards}

PhD in Geography from University College London (London/United Kingdom).

Professor of Placemaking and Events at Breda University of Applied Sciences (Breda/Netherlands).

E-mail: richards.g@buas.nl 


\section{Brazilian

\section{ABSTRACT}

This paper examines the position of crafts within the creative industries and considers how this has been affected by the growing links between the creative industries and tourism. A review of the creative industries concept indicates that crafts occupy an ambiguous position between art and tradition, which problematises their relationship with the creative industries. This is gradually changing at the creative and tourism sectors become more closely linked, and craft has become an important element of the development of creative tourism experiences. We review the role of craft in creative tourism, including case studies from Brazil, Finland, and Thailand, to examine how tourism can support the creative development of crafts. This analysis indicates that craft can be an important aspect of creative tourism development in different contexts and can provide a strong basis for placemaking initiatives.

Keywords: Creative industries. Creative tourism. Placemaking. Brazil. Finland. Thailand.

\section{RESUMO}

Este artigo examina a posição do artesanato nas indústrias criativas e considera como isso foi afetado pelos vínculos crescentes entre as indústrias criativas e o turismo. Uma revisão do conceito de indústrias criativas indica que o artesanato ocupa uma posição ambígua entre arte e tradição, o que problematiza sua relação com as indústrias criativas. Isso está mudando gradualmente nos setores criativos e de turismo que se tornaram mais estreitamente ligados, e o artesanato tornou-se um elemento importante do desenvolvimento de experiências de turismo criativo. Revisamos o papel do artesanato no turismo criativo, incluindo estudos de caso do Brasil, Finlândia e Tailândia, para examinar como o turismo pode apoiar o desenvolvimento criativo do artesanato. Esta análise indica que o artesanato pode ser um aspecto importante do desenvolvimento do turismo criativo em diferentes contextos e pode fornecer uma base sólida para iniciativas de placemaking.

Palavras-chave: Indústrias criativas. Turismo criativo. Placemaking. Brasil. Finlândia. Tailândia. 


\section{Brazilian

\section{INTRODUCTION}

Craft production is not only an important part of our cultural heritage, but it also provides an important contact between human culture and creativity and the material world. In recent decades, however, the status of craft has been under threat from mass production and the perceived superiority of industrial design over traditional technique. While in some areas craft producers have been able to re-valorize their activities as a form of art, in other cases makers have needed to seek alternative forms of revenue, including articulation with the tourism industry. In this sense, craft has followed a path now frequently seen in the creative industries as a whole, which have become increasingly closely related to tourism (OECD, 2014).

This conceptual paper analyses the developing relationship between craft and tourism, and how the position of craft as a creative industry has changed as a result. We review studies of the creative industries as these relate to the position of craft, and develop case studies of the relationship between craft and the creative industries in different areas of the world.

\section{CRAFT AS A CREATIVE INDUSTRY}

Craft has always struggled to be recognised as part of the creative industries. It tends to have a relatively peripheral position in the creative landscape, far from the 'core' creative industries. Most accounts of the development of the creative industries concept take as their starting point the sectoral definition of the creative industries proposed by the UK Department for Culture, Media and Sport (DCMS, 1998). The definition of the creative industries was "those industries which have their origin in individual creativity, skills and talent and which have a potential for wealth and job creation through the generation and exploitation of intellectual property" (DCMS, 1998, p. 3). Crafts was among these industries, which also included advertising, architecture, the art and antiques market, design, designer fashion, film, interactive leisure software, music, the performing arts, publishing, software and television and radio. This view of the creative industries was highly influential, and led a number of other countries to adopt fairly similar categorisations over the years (Table 1). A consideration of the frequency with which different sectors are included in creative industry classifications in Table 1 indicates that advertising, design, film, music, performing arts and publishing are always present. 


\section{Brazilian Creative Industries}

Table 1: Sectoral definitions of the creative industries by country

\begin{tabular}{|c|c|c|c|c|c|}
\hline $\begin{array}{c}\text { Australia } \\
\text { (Australian } \\
\text { Creative Industries } \\
\text { Innovation Centre, } \\
\text { 2013) }\end{array}$ & $\begin{array}{c}\text { Brazil (Firjan, } \\
\text { 2016) }\end{array}$ & $\begin{array}{c}\text { Germany } \\
\text { (German Federal } \\
\text { Ministry of Economics } \\
\text { \& Technology 2009) }\end{array}$ & $\begin{array}{c}\text { Indonesia } \\
\text { (Indonesia Kreatif } \\
\text { 2011) }\end{array}$ & $\begin{array}{c}\text { Korea } \\
\text { (Cultural Industry } \\
\text { Promotion Law } \\
\text { 2013) }\end{array}$ & $\begin{array}{l}\text { United Kingdom } \\
\text { (DCMS 1998) }\end{array}$ \\
\hline $\begin{array}{c}\text { Advertising \& } \\
\text { marketing }\end{array}$ & $\begin{array}{l}\text { Publicity \& } \\
\text { marketing }\end{array}$ & Advertising market & Advertising & Advertising & Advertising \\
\hline \multirow[t]{3}{*}{ Architecture } & Architecture & Architectural market & Architecture & & Architecture \\
\hline & & Art market & Art goods market & & $\begin{array}{c}\text { Art \& antiques } \\
\text { market }\end{array}$ \\
\hline & Crafts, folklore & & Handicraft & Craft & Crafts \\
\hline \multirow[t]{2}{*}{ Design } & Design & $\begin{array}{l}\text { Design } \\
\text { industry }\end{array}$ & Design & Design & Design \\
\hline & Fashion & & Fashion & & Fashion \\
\hline Film & Audiovisual & Film industry & $\begin{array}{l}\text { Film, video \& } \\
\text { photography }\end{array}$ & Film \& video & Film \& video \\
\hline Music & Music & Music industry & Music & Music & Music \\
\hline Performing arts & Scenic arts & $\begin{array}{c}\text { Performing art } \\
\text { market }\end{array}$ & Performance art & Performing art & Performing arts \\
\hline $\begin{array}{l}\text { Writing, publishing } \\
\text { \& print media }\end{array}$ & Publishing & $\begin{array}{c}\text { Book market, press } \\
\text { market }\end{array}$ & $\begin{array}{c}\text { Publishing \& } \\
\text { printing }\end{array}$ & $\begin{array}{c}\text { Publishing \& } \\
\text { printing }\end{array}$ & Publishing \\
\hline $\begin{array}{c}\text { Software } \\
\text { development \& } \\
\text { interactive content }\end{array}$ & $\begin{array}{l}\text { Information } \\
\text { technology }\end{array}$ & & $\begin{array}{l}\text { Computer service } \\
\text { \& software }\end{array}$ & & Software \\
\hline \multirow[t]{2}{*}{ Television \& radio } & & $\begin{array}{c}\text { Broadcasting } \\
\text { industry }\end{array}$ & Television \& radio & Broadcasting & Television \& radio \\
\hline & & $\begin{array}{c}\text { Games/software } \\
\text { industry }\end{array}$ & Interactive games & Games & $\begin{array}{l}\text { Video/computer } \\
\text { games }\end{array}$ \\
\hline \multirow[t]{4}{*}{ Visual arts } & & & & Art & \\
\hline & $\begin{array}{c}\text { Research \& } \\
\text { development }\end{array}$ & & $\begin{array}{c}\text { Research \& } \\
\text { development }\end{array}$ & $\begin{array}{c}\text { Cartoons/ } \\
\text { comics }\end{array}$ & \\
\hline & & & & Animation & \\
\hline & & & & Characters & \\
\hline
\end{tabular}




\section{Brazilian \\ Creative Industries}

\begin{tabular}{|l|l|l|l|l|l|}
\hline & & & & $\begin{array}{c}\text { Mobile cultural } \\
\text { content }\end{array}$ & \\
\hline & & & & $\begin{array}{c}\text { Digital cultural } \\
\text { Content }\end{array}$ & \\
\hline & & & Edutainment & \\
\hline & $\begin{array}{c}\text { Heritage and } \\
\text { arts }\end{array}$ & & & Cultural heritage & \\
\hline & Gastronomy & & & & \\
\hline & Biotechnology & & & & \\
\hline
\end{tabular}

These creative sectors are also broadly reflected in the concentric circles model developed by Throsby (2001), who argues that creative ideas originate in the 'core creative arts' and then disseminate outwards to the 'borderline' and 'peripheral' cultural industries. The core creative arts deal with the production of 'texts', both in old and new artforms, such as literature, music, the performing arts and the visual arts. The next layer includes industries such as film, television, publishing and video games, which have strong cultural content, and beyond this are remoter circles with industries like fashion, design and advertising, in which the cultural content is arguably lower. Craft is missing from the concentric circles model, as well as the 'symbolic texts' model of Hesmondhalgh (2007). In essence, craft bridges the older concept of the cultural industries and the more recent creative industries paradigm. The creative imagination of design involves creativity (usually conceived of as an immaterial process related to intellectual property) and uses raw materials, which ground craft in culture and the cultural industries.

Perhaps because of the strong links between craft and local places and cultures, they have gradually disappeared from many analyses of the creative industries. In the advanced economies, the creative industries are linked with ideas of innovation and contemporary production, whereas craft is usually linked with tradition and conserving the past. Those countries where craft is still seen as an important part of the creative industries tend to be emerging economies, where the temporal and cultural distance between craft and contemporary society is smaller. In many places, crafts have to be conserved as they are in danger of 'dying out', as Finastiian, Farsani and Mortazavi (2019). describe in their analysis of an interactive textile museum in Iran. Here, traditional and indigenous weaving methods and handicrafts are being revived for "last-chance tourism", or the increasing value of dwindling opportunities to see preindustrial creativity in action.

In other areas the social and cultural structures are more supportive of craft. In Brazil, for example, Firjan (2016) includes craft (artesanato) under 'cultural expressions', alongside folklore and gastronomy (folclore, gastronomia) (FERREIRA FILHO; DE LIMA; LINS, 2019). Borges (2019) notes that the Brazilian 


\section{Brazilian \\ Creative Industries}

concept of craft is less associated with the skilled artisan and more with a collective process of producing goods for use, socially transmitted over generations. In this context, the placing of craft under culture rather than creativity makes sense, and brings the Brazilian understanding of craft more in line with the narrow view of the cultural industries rather than the broader creative industries. The separation of creativity and culture is more prevalent in the western academic literature (KUGAPI, HUHMARNIEMI; LAIVAMAA, 2020), which tends to focus more on artists, rather than craft workers. In Finnish Lapland, where practices in art, craft and design have traditionally been understood as the same (HÄRKÖNEN; HUHMARNIEMI; JOKELA, 2018).

The separation of creativity from culture and craft has also downgraded the role of materials in the creative process. In the advanced economies, the transition to knowledge as the most important raw material of the creative industries has produced a downgrading of the role of materials as a source of value creation. The use of intellectual property as a definition of the creative industries (DCMS, 1998) is one marker of this transition. Because craft production is usually based on traditional techniques and socially-produced knowledge, it falls outside the scope of the intellectual property system, and therefore logically outside the DCMS (1998) definition (interestingly, as Table 1 shows, craft was included as a creative sector in the 1998 report, but it has subsequently been omitted from definitions and analyses of the creative industries in the UK). Craft, and other sectors not based on intellectual property, have tended to be marginalised in the recent growth of the creative industries. In the UK, for example, the Digital Sector alone accounted for half of the creative industries Gross Value Added in 2015 (DCMS, 2016). Craft, on the other hand, is a relatively small economic sector in the advanced economies. In the UK, craft accounted for sales of $\mathrm{f} 3 \mathrm{bn}$ in 2019, a very small amount compared with the total creative industries sector turnover of $\mathrm{f} 159$ billion in 2019 (DCMS, 2021). Research by the UK Crafts Council (2020) also indicated that the average price per craft object decreased from $\mathrm{f} 157$ in 2006 to $\mathrm{f} 124$ in 2020.

The shift from the cultural industries towards the creative industries has also tended to highlight economic value as the main determinant of the importance of particular creative activities. This has also stimulated more articulation between the creative industries and tourism, as a means of capturing economic value, and particularly stimulating exports from the creative sectors (OECD, 2014). However, other sources of value, such as symbolic and social value, can be produced by the craft industries. In particular, the advocates of craft point to the importance of craft in creating a link between society and the material world, and therefore with the environment. Arguably, craft can give us an appreciation of the world around us, as well as of the creative skill of makers and the importance of cultural symbols. 


\section{Brazilian \\ Creative Industries}

This paper considers how the recent integration of craft into modern economies through tourism has impacted on the creative and artistic process, and how tourism has helped to re-establish the social dimension of craft production through co-creation between makers and tourists.

\section{VALORIZING CRAFT THROUGH CREATIVE TOURISM}

The origins of the creative tourism concept go back to the mid-1990s, when a group of researchers and practitioners were looking at ways to enhance the sales of craft products to tourists (RICHARDS, 2005). The basic aim of the EUROTEX project was to support craft production by marketing local products more effectively to tourists. One of the biggest challenges for craft producers was distinguishing their high-value hand-made products from the cheaper mass-produced items often sold as souvenirs. Unless the tourists can appreciate the work and skill that goes into making handcrafted products, they are unlikely to want to pay more for them. Through discussions with craft producers and interviews with tourists, we established that many visitors were interested in seeing how craft products were made and wanted to learn craft skills. We therefore developed craft experiences that enabled visitors to get involved with the craft production process, either by seeing craft producers at work or by learning particular textile production techniques. These basic ideas laid the groundwork for what was later termed 'creative tourism' (RICHARDS, 2009).

It is no coincidence that the original inspiration for creative tourism came from craft. The essence of craft is working with materials - using the material world as an inspiration for creativity and innovation. As one fibre craftsperson put it:

\footnotetext{
when I study spinning and I use 100-year-old spinning wheels, I feel a kinship to artisans past whose feet and hands moved as mine are moving today. When I buy fleece from farms, I feel the cycles of seasons and the environmental factors affecting this year's clip. When I browse the Internet to gauge availability and pricing of handspun yarn, I feel connected to the legions of contemporary crafters who post their stories and products on blogs, on YouTube, and on Etsy.

My shorthand for all this is 'the world begins with fiber'.
}

The affinity with materials and their place in the world is the basis of craft. This is important because in a globalizing world it is easy to lose sight of the grounding of practices in materials. But this is precisely the approach taken by Shove and her collaborators (SHOVE; PANTZAR; WATSON, 2012). Social practices 


\title{
Brazilian \\ Creative Industries
}

are grounded in materials, which are then used through the application of skills and competences, which give meaning to the practice, and thereby also to the material being employed.

Craft requires skills and competences, but also a certain world view, and a sense of place. Anchoring craft in place becomes the antidote to globalisation, to the loss of place. It becomes a means of communicating, not only with the local community, but also with people from elsewhere, as the "Renaissance Woodworker" explains:

\begin{abstract}
Every Saturday from May through October you will find me in the woodshop at The Steppingstone Museum. For 3-5 hours (depending on event schedules) I am making shavings and talking to visitors about woodworking with hand tools and the history of the museum shop. I meet a lot of great people, dig up old memories (tears have been shed), and even ignite some new passions. This year especially I have seen many repeat visitors who caught the bug one week then came back for more in subsequent weeks. I'm making lovers of making. Even if my visitors never take up a woodworking tool again but rather go home and make pottery or (gasp) knit a sweater, that moment with tool in hand was the catalyst for a making renaissance in their own life. (ROGERS, 2020).
\end{abstract}

As Sarantou, Kugapi and Huhmarniemi (2020) have pointed out, many craftspeople want to engage with tourists, but are uncertain about the effects this will have on their craft. They do not want to give up making individually crafted high-value objects and cater for tourist markets with inexpensive, lower quality items. Of course, this view of the tourist market is based on traditional ideas about mass tourism: a form of consumption based on low prices and high volumes. This is a phenomenon that in recent years has also become attached to cultural tourism as the market has grown and the price of travelling to most places has fallen. The rise of 'mass cultural tourism' (Richards, 2021a) is a potential threat to small-scale crafts producers, who are largely unable to compete with mass produced goods from China.

One potential solution, as Richards, Onderwater and Stam (2000) have suggested, is to increase the engagement of tourists with crafts and local culture. When tourists build a relationship with the people and places they travel to, they appreciate the value of the experiences they have and the local crafts they encounter. If they spend time with a craftsperson, as in the woodworking example above, they see how much work and skill goes into craft production, and they will be more willing to pay for high quality, individualised goods. Even more importantly, they will value the experience of being in the place and interacting with people, increasing their connection and their likelihood of returning and recommending.

These ideas were the foundation for the development of the creative tourism concept. In 2000, Richards and Raymond defined creative tourism as: "Tourism which offers visitors the opportunity to 


\section{Brazilian

develop their creative potential through active participation in learning experiences which are characteristic of the holiday destination where they are undertaken".

It is easy to see how craft fits into this model. Craft is based on tacit knowledge, which needs to be passed from one person to another. Personal contact and communication are basic to creative tourism. Crafts are also embedded in place, linking the local materials, culture and landscape in the production of objects. People have a desire to learn about places and their cultures, and creative tourism provides learning opportunities which are directly linked to local people and their way of life. This active, productionbased form of tourism is very different from the relative passive consumption of culture represented by mass cultural tourism.

People who want to share their creativity and skills with each other are likely to form more lasting relationships than hotel staff and their guests. Learning a skill involves extensive face to face contact with those who have the skills we are seeking. The focus on skills also removes the problem of the language barrier that usually restricts entry to the tourist market. Sharing interest in skill is a great leveller-it can reduce barriers of gender, class, and origin. The common (often non-verbal) language of making and doing is an important form of communication. (RICHARDS, 2021b, p. 289).

Creative tourism also provides opportunities for craft producers to valorise their craft and generate more value from their activities. As the economy has developed, there has been a progression of economic value, from low value exchanges based on commodities, to increasingly higher value transactions of goods and services. And the contemporary experience economy provides even higher value for the consumer, linking them to important themes and generating education, entertainment, aesthetic value and excitement. According to Pine and Gilmore (1999) we should now be moving towards a transformation economy, in which people seek experiences that will change them as human beings. We see this reflected in the growth of yoga, language learning, cookery classes and the search for spiritual transformation.

In the transformation economy, people are seeking knowledge and skills that will help them deal with the challenges they face, become better people or to create a better world. This trend lies behind the growing interest in craft, which Richard Sennett (2009) describes in detail in his book The Craftsman. He argues that craft is not just a way to get back in touch with the material world, but also a means of thinking about the world, and thinking about how to improve it.

Catering to the desire of people to know more about materials and craft through the provision of creative experiences has the potential to increase the economic value of tourism for crafts. Active involvement with materials and their manipulation by skilled craftspeople allows tourists to appreciate 


\section{Brazilian Creative Industries}

the value of craft objects, and therefore also increases their willingness to pay for them. Even more importantly, many tourists are now want the experience of learning from others, for the acquisition of new skills and ideas that they can use in their daily lives as well. The creative experience of learning from a craftsperson is therefore much more valuable as a transformational experience than the basic raw materials, or even the good or services that can be produced from them. The craft experience is priceless because it is individual, customised and unique. Unlike many cultural tourism experiences, creative tourism also involves more direct relationships between the tourists and people in the place they are visiting, and the culture, creativity and genius loci of the place itself.

Figure 1: The progression of economic value through different modes of consumption

\section{Crafting value through creativity}

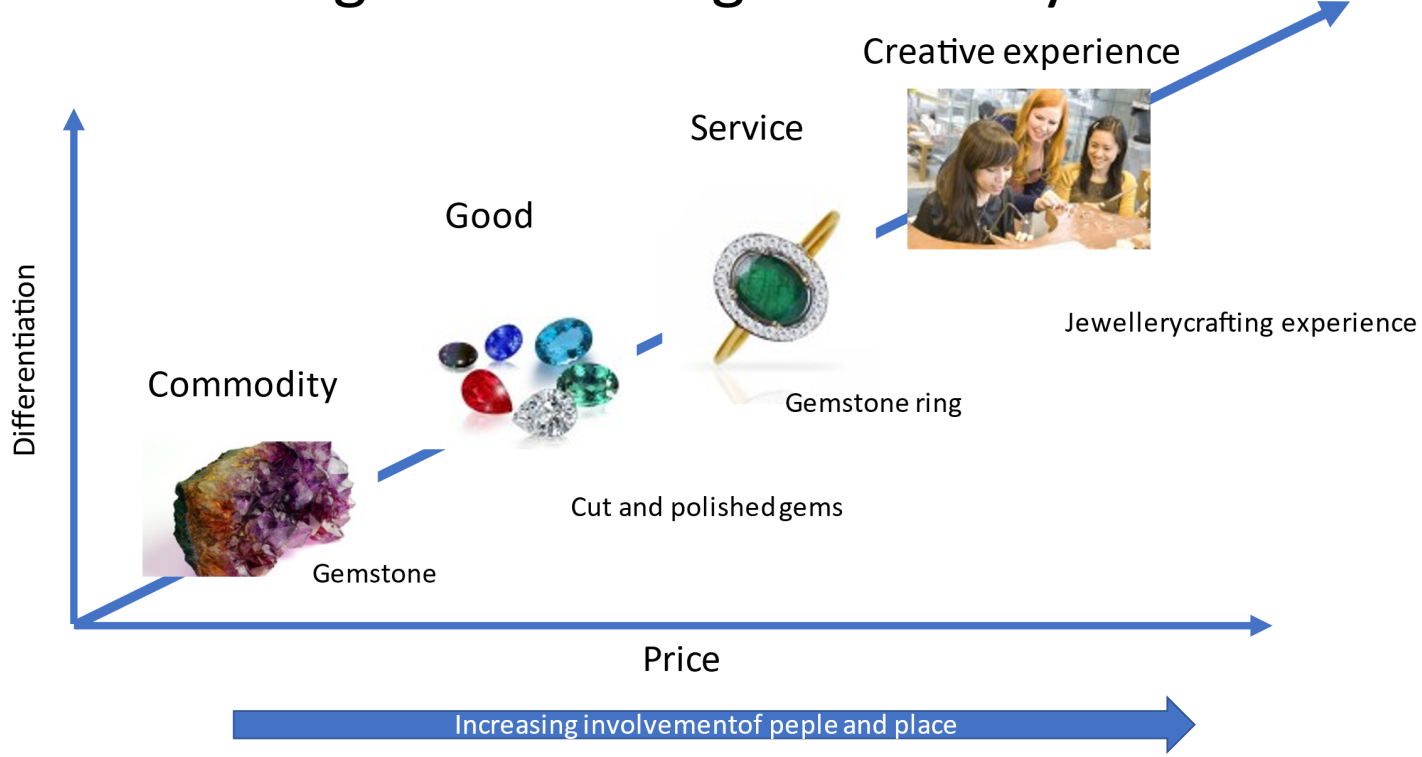

These relationships are also important to the value creation process, because they influence the way in which the social, cultural and economic value of craft is established. By transforming materials into goods, services and then finally experiences for consumers, the economic value of the original product is increased manyfold, as Pine and Gilmore (1999) argue in their concept of the experience economy (Figure 1). Creative tourism is essentially an experience that increases the value of the materials used by adding a relational dimension: the connection between maker and consumer. This relationship provides a frame in which the value of creativity is increased, and the basic craft product is transformed from a simple object for use into the creative performance of a story or narrative that connects people and gives a personal 


\section{Brazilian \\ Creative Industries}

value to the experience and the object. In this sense, the value of craft is much more than economic. It can produce different types of value in different ways:

- By linking people and place - with the emphasis of craft on materials, sensory value, communication and storytelling.

- By instilling authenticity - linking to the origins of objects and skills, and to the maker themselves

- Crafts increase the skills that can be passed from person to person.

- Craft provides an alternative to mass production and consumption, more suited to sustainable lifestyles.

In particular, we are likely to see a renaissance of crafting as a result of the Covid-19 pandemic. Not only have people rediscovered their own creativity during the lockdown - they have also been rediscovering place (and the value of local places) and re-valuing the rural. More people are also in search of small places, which tend to have higher concentrations of craftspeople.

To benefit from these new opportunities, the crafts sector will need to consider new ways of positioning itself. Most importantly, the current modes of cultural tourism that emphasise passive sightseeing should be superseded by more active modes of creative tourism that emphasise holistic placemaking approaches instead of place marketing, increasing the involvement of both local people and visitors, and developing the human connections between them. In re-thinking craft for more creative modes of tourism, we need to identify the touchpoints that can increase visitor involvement. We need to think about ways of linking people and place through storytelling. Stories of place should not just be about the location itself, but they should also provide touchpoints that link to the culture and creativity of the visitor as well. Increased visitor involvement and relationality will lead to higher purchase probability, generating economic as well as creative and relational value.

These principles are illustrated in the following section through some case studies of creative tourism development and craft in Finland, Brazil and Thailand.

\section{CASES OF CRAFT DEVELOPMENT THROUGH CREATIVE TOURISM}

\subsection{FINLAND}

Finnish Lapland was one of the pilot project regions for the development of the EUROTEX Project. When this project started in the late 1990s, there were considerable challenges in sustaining craft production is a sparsely populated area of a rapidly modernising society. The project was closely linked to initiatives by the Finnish Crafts Council to increase the income of makers by stimulating direct sales to 


\section{Brazilian \\ Creative Industries}

consumers. This included the development of a website featuring crafts products from makers all over Lapland, as well as the development of creative tourism experiences. Creative tourism was successful in supporting sales of craft objects to tourists, and in conserving particular traditional techniques, which could also generate income through courses and teaching craft skills to tourists (MIETTINEN; ERKKILÄHILL; KOISTINEN; JOKELA; HILTUNEN, 2019).

The development of crafts production and the articulation with tourism has continued through projects such as the Handmade in Lapland (2018) project funded by the European Social Fund and numerous projects related to arts and crafts (HUHMARNIEMI; JOKELA, 2020). The development of craftbased tourism is seen as a means of combatting seasonality (KUGAPI et al., 2020), although this also requires new skills from the producers.

One means of resisting the pressures of industrialisation and globalisation on the crafts industries is to embed them in place. Huhmarniemi and Jokela (2020) describe the use of local knowledge as a basis for creativity and placemaking, particularly through indigenous Sámi culture. They argue that a distinctive "northern knowledge system" is developing in this artic region, which combines situated knowledge integrated with the ecoculture and living traditions. This knowledge can be carried and shared in situated learning, as in the case of creative tourism. Situated knowledge is an interesting basis for creative tourism, because it can only be transferred through personal contact in situ, which means that travel is the only option for those who wish to acquire such knowledge.

In creative tourism experiences, one of the main pathways of knowledge sharing is storytelling. Sarantou et al. (2020) emphasise the value of developing personal relationships between craft people and tourists through storytelling: "When a tourist comes to my workshop, I can make up a story about how I work, and this adds value. People want to know why I have done something, how it was done".

Making creative tourism work well is far from easy. The Lappish designer-makers saw tourism as an opportunity to sustain their livelihoods, but they grappled with finding a balance between the production of luxury products with limited sales and more inexpensive products for the tourism market with larger volumes of sales. However, designer-makers often do not have to adopt an 'either-or' approach. In fact, an 'and-and' approach may enable them to produce and enjoy the production of a variety of tourist art or products.

This search for balance between creative lifestyles and economic sustainability has stimulated a search for broader approaches to the relationship between craft, creative industries and tourism, based on 'placemaking.' As Kugapi et al. (2020) describe, there is a need for individual craft producers to collaborate through networks to overcome the challenges of seasonality and competition from manufactured souvenirs. They argue that involvement in creative tourism decreases the consumption of tourist art, or 


\section{Brazilian

mass-produced souvenirs. But there remains a challenge of growing craft businesses, which are often lifestyle businesses. For example, one problem is the shortage of space for creative tourism activities. In a cold climate such as Lapland, indoor space is a must for crafting activities, and creative learning requires even more space. Kugapi et al. (2020) suggest that common creative spaces in tourist areas might make it easier for craft people to become engaged in creative tourism. The development of creative experiences might also help to address the contradiction of souvenir shops in Lapland selling imported souvenirs while tourists are looking for more locally made products.

Lapland is developing a vision that: "In the future, Lapland will be a well-known destination for craft-based tourism. Travellers will come here to buy craft kits and materials as well as to participate in workshops and other services." In this move towards a 'Craftier Future' the development of creative tourism becomes one way of sharing creative lifestyles with tourists, enabling many lifestyle crafters to integrate their craft production with the needs of the market. In effect, craft workers are able to balance their work and lifestyle needs by engaging tourists in a broader system of placemaking, adding value by capitalising on place, culture, local knowledge rather than through narrow economic transactions.

\subsection{BRAZIL}

As noted above, in the Brazilian context craft has a stronger social and collective dimension than is evident in northern countries such as Finland. Much attention has therefore been focussed on developing craft as a creative industry that can support communities economically as well as underpinning traditional cultures. This is also evident in creative tourism programmes, which in Brazil have often been employed as a form of community development rather than as a support for individual artisans.

The development of creative tourism in Brazil started in Porto Alegre in southern Brazil which in 2013 developed 40 different creative workshops and experiences, available to residents and visitors (NIQUINI, 2019). A mapping exercise was undertaken to identify potential creative tourism experiences. The themes range from crafts, fandango, making and drinking mate to the traditional churrasco or barbeque of the region. The idea was to enable tourists to interact in various ways with these experiences, for example by learning traditional dances or preparing traditional food themselves. Porto Alegre also shared its experience with a number of other destinations in Brazil, which also inspired other local initiatives and programmes, eventually leading to the formation of RECRIA (Rede Nacional de Turismo Criativo).

The RECRIA network is coordinated from Recife in Pernambuco, where there are a number of different creative tourism experiences emerging thanks to the activities of the local creative sector. These include the 'Playtown' project, which allows residents and visitors to interact with creative artifacts in the historic centre of the city (MARQUES; BORBA, 2017). The Bomba do Hemeterio neighbourhood 


\section{Brazilian \\ Creative Industries}

also invites tourists to become involved in the activities of local cultural groups, including crafting and Carnival performances. Research by Alan Jones Santos do Nascimento (2014) indicated that this project has brought significant benefits. Around $80 \%$ of businesses in the area indicated that there had been improvements in trade, with $37.5 \%$ indicating increased profitability and $25 \%$ citing increased customer flows. Many residents have participated in professional training through the programme, and $70 \%$ of residents felt there had been an improvement in tourist itineraries. Bomba is the largest artistic cluster in the city, and has also become a centre for craft and creative tourism. Visitors can "meet the people who make the Carnival of Recife happen, participate in workshops to make costumes and props and even learn the first touches of maracatu. All of this to go out on a parade through the streets of the neighborhood as if he were playing in Momo's revelry." Based on these developments, Recife dubbed itself "Capital da Criatividade e do Turismo Criativo" in 2020.

In many areas of Brazil, creative tourism is now being developed, frequently on the basis of crafts. For example, Lewandowski (2016) describes the development of crafts for creative tourism in Salvador, including the staging of ceramic workshops, bobbin lace workshops, and glass crafting. The city sees the development of such creative activities as providing social inclusion for residents, as well as economic opportunities through the development of tourism. The development of creative destinations is described in a number of areas by dos Anjos, Borba and Gurkewicz (2021). These include Paraty, where workshops are organised to integrate design, crafts, folklore, art and gastronomy. The recognition of Florianópolis as a creative gastronomic city by UNESCO is also supported by activities related to design and crafts. In Alagoas, Cavalcante \& Fonseca (2021) analysed the potential of craft experiences based on ceramics, textiles, although they note a number of constraints, including the lack of accommodation for visitors. Developing engagement with local artisans is also noted as a challenge in the case of São Luís (Maranhão) (DE CARVALHO; CUTRIM; DA COSTA, 2017).

In the Brazilian context, therefore, creative tourism has emerged as a vehicle for a wide range of value-creation activities, including economic support for craft industries, but also a wider range of social and destination branding activities than seen in Finnish Lapland.

\subsection{THAILAND}

Thailand has been spearheading the development of creative tourism as a way of adding value to tourism experiences and supporting local creative development. The creative tourism programme run by the national Designated Areas for Sustainable Tourism Administration (DASTA) has developed a network of villages that provide creative experiences for visitors. These experiences are often based on traditional arts and crafts, with the application of contemporary creativity (WISANSING, 2016). Crafts experiences 


\section{Brazilian

developed in the creative villages supported by DASTA include making Buddhist votive images, weaving textiles and baskets and making and painting ceramics.

The creative tourism programme in Thailand has given extensive support to crafts producers, enabling them to engage more effectively with tourists. DASTA has produced a Creating Creative Tourism Toolkit (RICHARDS; WISANSING; PASCHINGER, 2019), which provides local communities with ideas and guidance on developing creative experiences. This includes many aspects of experience design, with an emphasis on storytelling as a link between crafts producers and visitors. Interesting, many of the participants in the creative tourism programme are Thai domestic tourists and locals curious to find out more about the crafts that are on their doorstep.

One of the important aspects of Thailand's creative tourism programme is the development of relationships between visitors, creators and residents. These encounters are a means of exchanging values, knowledge and skills that can increase the creativity of all involved. Such relational models of creative tourism also support Thailand's drive towards 'high value tourism', because the personalised nature of the creative experience is worth much more than the packaged experiences offered to mass tourists.

The development of creative tourism in Thailand is very clearly related to the national policy of developing the creative industries. A national policy to boost the creative economy was launched in 2009 with the aim of reducing dependency on primary and secondary industries. Given the importance of tourism in Thailand, it was also logical that the country aspired to become 'the first creative tourism destination in Asia' (WATTANACHAROENSIL; SCHUCKERT, 2016). The development of creative tourism has therefore enjoyed active public sector support and is strongly linked to the development of sustainable tourism in rural areas. Although these activities help to conserve craft activities in local communities, the strong social orientation seen in Brazil is lacking in the Thai context.

\section{DISCUSSION AND CONCLUSIONS}

Craft has tended to be a poor relation of the creative industries, particularly in advanced economies where it has been seen as inferior to artistic creativity. However, this position has changed in recent years, also thanks to the growing relationship between craft and tourism, which has brought a wider audience into contact with craft producers and craft production. In particular, the growing popularity of creative tourism has boosted the activities of local networks of craft producers and stimulated a more place-based approach to the development of crafts. 


\section{Brazilian \\ Creative Industries}

Arguably, the social transmission of skills and techniques in Brazil and other emerging economies is more attuned to the articulation with tourism than the prevalent western view of craft as based on individual skill. This explains the frequent positioning of creative tourism as a tool for social inclusion in Brazil, in contrast with the more market-orientated approach seen in Finland, Thailand and many other creative tourism destinations. Developing a more social approach to craft and creative tourism can also be a means of supporting local communities and developing a stronger sense of place, promoting more direct and active contact between local people and visitors.

However, the development of creative tourism and craft experiences face a number of challenges, particularly in the post-pandemic era. These relate to:

- Preserving the identity of craftspeople

- Moving away from a purely economic relationship with tourism

- Engaging younger generations in craft activities

- Engaging with tourists as people or creative actors rather than as an economic resource.

In the craft sector, it is important to develop opportunities for younger people. Unless craft skills, and even more importantly a love of materials and technique, are passed on to future generations then crafts will find it difficult to survive. This is a particular challenge in rural and sparsely populated areas. By taking traditional crafts and retrofitting them to be attractive to new generations, the pool of craft producers and the potential tourism market could be expanded as well (RICHARDS, 2021b).

The fact that craft has an intimate relationship to place should also be an important part of this regeneration. Providing economic opportunities through craft and tourism is just one part of the story. Places should be though about in a more holistic way that makes them more attractive to live in, not just to visit. Arguably a more holistic approach to making places better depends on the links between resources, meaning and creativity (RICHARDS, 2020). Craft can contribute to all three of these areas, by highlighting the materials that are linked to places, giving these meaning through storytelling that links these materials to people and place, and using the creativity of craft producers to develop and expand the meanings of craft objects and make them relevant for all - not just tourists.

The aim of creative tourism development should be crafting better places for all the people who live, work, visit and invest in them. If we start thinking in this more holistic way, it is also possible to think about how craft can be employed as a tool for future development, not just as a means of preserving the past for cultural tourists. The 'new craft era' can potentially invert the traditional logic of innovation, by:

- Emphasising quality over quantity

- Making better use of scarce materials and revaluing labour

- Increasing design intensity 


\section{Brazilian \\ Creative Industries}

- Retrofitting traditional solutions to contemporary problems

- Developing experiences that provide productive creative possibilities instead of passive consumption

Engaging the creativity of crafts producers in a future-oriented way means making links between local places, with their embedded creativity, and the global flows of people and resources, of which tourism is one part. We see creative tourism as a 'glocal' strategy, in opposition to the serial reproduction stimulated by globalisation.

At the current point in our journey with craft we can see that the relationship between craft, culture and tourism has developed rapidly over the past two decades. From the simple manufacture of objects to sell to tourists, we now see a growing creative role for crafts producers in creating links with people who visit, and making places come alive for them. What people take home with them is no longer just souvenirs, but as Richard Sennett (2009) suggests, a whole new way of looking at the world.

\section{ACKNOWLEDGEMENT}

This paper is based on presentation to the World Crafts Council Europe webinar on Craft and Tourism, November $27^{\text {th }}, 2020$. I am grateful to the participants in this conference and a subsequent Academia.edu discussion for comments on the paper.

\section{REFERENCES}

AUSTRALIAN CREATIVE INDUSTRIES INNOVATION CENTRE. Valuing Australia's creative industries Final report, SGS Economics and Planning Pty Ltd, Brisbane, Australia, 2013. Available in: www.creativeinnovation.net.au/ce_report/webapp/static/pdfs/CIIC-Valuing-Australias-Creative-Industries-2013. pdf. Access on:

BORGES, A. Design + Artesanato: o caminho brasileiro. São Paulo: Editora Terceiro Nome, 2019.

CAVALCANTE, M. M.; FONSECA, D. D. B. C. Turismo criativo como estratégia de desenvolvimento: o caso de União dos Palmares, Alagoas. RITUR-Revista Iberoamericana de Turismo, 11(1), 264-286. 2021.

CRAFTS COUNCIL. The Market for Craft. London: The Crafts Council, 2020.

DCMS. Creative industries mapping document. London: DCMS, 1998. 


\section{Brazilian \\ Creative Industries}

DCMS. DCMS Sectors Economic Estimates August 2016. London: DCMS, 2016. Available in: https://assets.publishing.service.gov.uk/government/uploads/system/uploads/attachment_data/file/544103/ DCMS_Sectors_Economic_Estimates_-_August_2016.pdf. Access on:

DCMS. DCMS Economic Estimates 2019 (provisional): Gross Value Added. London: DCMS, 2021. Available in: https://www.gov.uk/government/statistics/dcms-economic-estimates-2019-gross-value-added/dcms-economic-estimates-2019-provisional-gross-value-added. Access on:

DE CARVALHO, C. D. M. B.; CUTRIM, K. D. G.; DA COSTA, S. R. Empreendedorismo cultural e turismo: perspectivas para desenvolvimento das indústrias criativas no bairro da Madre Deus, São Luís (Maranhão, Brasil). Boletim do Museu Paraense Emílio Goeldi. Ciências Humanas, 12(2), 629-646. 2017.

DOS ANJOS, F. A.; BORBA, M. S. B.; GURKEWICZ, F. C. Destino turístico criativo: estado da arte sobre turismo, gastronomia e cidades criativas em bases de dados nacionais e internacionais. RITUR-Revista Iberoamericana de Turismo, 11(1), 191-208. 2021.

GERMAN FEDERAL MINISTRY OF ECONOMICS AND TECHNOLOGY (BMWi). Monitoring of Selected Economic Key Data on Culture and Creative Industries 2011. Berlin: BMWi, 2011. Available in: www. kulturwirtschaft.de/wpcontent/uploads/2013/06/DE-CCI2011-shortversion.pdf. Access on:

FERREIRA, J.; SOUSA, B. M.; GONÇALVES, F. Encouraging the subsistence artisan entrepreneurship in handicraft and creative contexts. Journal of Enterprising Communities, 13(1-2), 64-83. 2019. Available in: https://doi.org/10.1108/JEC-09-2018-0068 Access on:

FINASTIIAN, M.; FARSANI, N.T.; MORTAZAVI, M. Traditional weaving house in Isfahan as a museum for promoting last-chance tourism. Museum Management and Curatorship, 34(4), 448-461. 2019.

FIRJAN - FEDERAÇÃO DAS INDÚSTRIAS DO ESTADO DO RIO DE JANEIRO. Indústria criativa. Mapeamento da indústria criativa no Brasil. Rio de Janeiro: FIRJAN, 2016.

HÄRKÖNEN, E.; HUHMARNIEMI, M.; JOKELA, T. Crafting sustainability: Handcraft in contemporary art and cultural sustainability in the Finnish Lapland. Sustainability, 10(6), 1907. 2018.

HESMONDHALGH, D. The Cultural Industries. London: SAGE, 2007.

HUHMARNIEMI, M.; JOKELA, T. Arctic art and material culture: Northern knowledge and cultural resilience in the northernmost Europe. Arctic yearbook, 2020, 242-259. 2020. Available in: https://arcticyearbook.com/. Access on: 


\section{Brazilian Creative Industries}

INDONESIA KREATIF. Rencana Strategis Kepariwisataan dan Ekonomi Kreatif Periode 2012-2014 ("Strategic Plan of Tourism and Creative Economy 2012-2014"). Indonesia Kreatif, Jakarta, 2013. Available in: http://gov.indonesiakreatif.net/publication/renstra-kepariwisataan-dan-ekonomi-kreatif. Access on:

JONES SANTOS DO NASCIMENTO, A. Polo Cultural Da Bomba Do Hemetério: Um Olhar Sobre O Programa Bombando Cidadania. Recife: Centro Universitário Maurício de Nassau do Recife, 2014.

KOREA CREATIVE CONTENT AGENCY. Content Industry Statistics 2013. Seul: KOCCA, 2013. Available in: www.kocca.kr. Access on:

KUGAPI, O.; HUHMARNIEMI, M.; LAIVAMAA, L. A potential treasure for tourism: Crafts as employment and a cultural experience service in the Nordic North. In: Tourism Employment in Nordic Countries (pp. 77-99). Cham: Palgrave Macmillan, 2020.

LEWANDOWSKI, S. A. Turismo criativo-experiências Soteropolitana. Fólio-Revista Científica Digital-Jornalismo, Publicidade e Turismo, 17(1), 133-144. 2016.

MARQUES, L.; BORBA, C. Co-creating the city: Digital technology and creative tourism. Tourism management perspectives, 24, 86-93. 2017.

MIETTINEN, S.; ERKKILÄ-HILL, J.; KOISTINEN, S. M.; JOKELA, T.; HILTUNEN, M. Stories of design, snow, and silence: creative tourism landscape in Lapland. In: A Research Agenda for Creative Tourism. Edward Elgar Publishing, 2019.

NIQUINI, W. T. R. Política pública de turismo em nível municipal: o caso do Programa Porto Alegre Turismo Criativo. Viçosa: Universidade Federal de Viçosa, 2019.

OECD. Tourism and the Creative Economy. Paris: OECD, 2014.

PINE, B. J.; GILMORE, J. H. The experience economy: work is theatre \& every business a stage. Cambridge: Harvard Business Press, 1999.

RICHARDS, G. Textile Tourists in the European Periphery: New Markets for Disadvantaged Areas? Tourism Review International, 8(4), 323-338. 2005.

RICHARDS, G. Creative tourism and local development. In: WURZBURGER, R.; PATTAKOS, A.; PRATT, S. (eds). Creative Tourism: A global conversation. Santa Fe: Sunstone Press, 2009, pp. 78-90. 


\section{Brazilian Creative Industries}

RICHARDS, G. Designing Creative Places: The role of creative tourism. Annals of Tourism Research. 2020. Available in: https://doi.org/10.1016/j.annals.2020.102922. Access on:

RICHARDS, G. Rethinking Cultural Tourism. Cheltenham: Edward Elgar, $2021 \mathrm{a}$.

RICHARDS, G. Creative Placemaking Strategies in Smaller Communities. In: KATHLEEN SCHERF, K. (ed.). Creative Tourism in Smaller Communities: Place, culture, and local representation. Calgary: University of Calgary Press, 2021b, pp. 283-297.

RICHARDS, G.; ONDERWATER, L.; STAM, S. Why tourists buy textile souvenirs: European evidence. Tourism, Culture and Communication, 2(1), 39-48. 2000.

RICHARDS, G.; RAYMOND, C. Creative tourism. ATLAS news, 23(8), 16-20. 2000.

RICHARDS, G.; WISANSING, J.; PASCHINGER, E. Creating Creative Tourism Toolkit. Bangkok: DASTA, 2019 (Second edition).

ROGERS, S. Renaissance Woodworker. 2020. Available in: https://www.renaissancewoodworker.com/ a-whole-lotta-woodworking-with-nothing-to-show-for-it/. Access on:

SARANTOU, M.; KUGAPI, O.; HUHMARNIEMI, M. Context mapping for creative tourism. Annals of Tourism Research, 86, 103064. 2020.

SENNETT, R. The Craftsman. New Haven: Yale University Press, 2009.

SHOVE, E.; PANTZAR, M.; WATSON, M. The dynamics of social practice: Everyday life and how it changes. London: Sage, 2012.

THROSBY. Economics and Culture. Cambridge: Cambridge University Press, 2001.

WATTANACHAROENSIL, W.; SCHUCKERT, M. Reviewing Thailand's master plans and policies: implications for creative tourism? Current Issues in Tourism, 19(10), 1045-1070. 2016. 